\title{
Plasmin and coagulant activities in a minicurd model system: Study of technological parameters
}

\author{
M. A. Vélez, ${ }^{1}$ M. C. Perotti, M. C. Candioti, C. V. Bergamini, and E. R. Hynes \\ Instituto de Lactologia Industrial (INLAIN), Universidad Nacional del Litoral/Consejo Nacional de Investigaciones Cientificas y Tecnicas \\ (UNL/CONICET), Facultad de Ingenieria Quimica (FIQ), Santiago del Estero 2829, S3000AOM Santa Fe, Argentina
}

\begin{abstract}
The effect of scalding temperature of the curd, the inclusion of a washing step, and the $\mathrm{pH}$ at whey drainage on plasmin and coagulant activities were assessed in a minicurd model of young hard cooked cheese. The variables were tested as follows: draining $\mathrm{pH}$ was assayed at 3 levels $(4.6,5.6$, and 6.4), curd scalding temperature was tested at 50 and $56^{\circ} \mathrm{C}$, and washing of the curd was examined at 2 levels (no washing step, and the replacement of the whey by water). Increase in $\mathrm{pH}$ at whey drainage and washing of the curd had a positive effect on plasmin activity, which was also evidenced by compatible changes in soluble peptide profiles. No effect of increased cooking temperature was found on plasmin activity. Plasminogen activation was not verified in any treatment. As for coagulant, lower $\mathrm{pH}$ values at whey drainage and a decrease in curd cooking temperature increased its activity; washing of the curd showed no influence on coagulant residual activity. These results were consistent with proteolysis described by peptide profiles, electrophoresis, and soluble nitrogen fractions. Key words: plasmin, coagulant, minicurd model, hard cheese
\end{abstract}

\section{INTRODUCTION}

Proteolysis involves biochemical events that confer cheese unique characteristics of taste, aroma, and texture specific of each variety. The initial breakdown of caseins during cheese ripening is due to the residual coagulant and the indigenous enzyme plasmin, which results in the production of large and mid-sized peptides.

Plasmin (EC 3.4.21.7) is a serine proteinase derived from blood; its optimal $\mathrm{pH}$ and temperature are 7.5 and $37^{\circ} \mathrm{C}$. In milk, it preferentially hydrolyzes $\beta$-casein into

Received December 22, 2015.

Accepted May 31, 2016.

${ }^{1}$ Corresponding author: mvelez@fiq.unl.edu.ar $\gamma$-caseins, but it can also hydrolyze $\alpha_{\mathrm{S} 2}$-casein (Rampilli and Raja, 1998). Plasmin belongs to a complex system that includes the active enzyme, its inactive precursor plasminogen, plasminogen activators, and 2 inhibitors: the enzyme inhibitor and the plasminogen activators inhibitors. Whereas the proteinase inhibitors are located in the whey fraction of milk, plasmin is predominantly bound to the casein micelles (Grufferty and Fox, 1988). Thermal stability of plasmin is relatively high, as a temperature of $80^{\circ} \mathrm{C}$ for $10 \mathrm{~min}$ is required for full inactivation of the enzyme; on the contrary, inhibitors are heat labile (Somers and Kelly, 2002). Therefore, the contribution of plasmin to primary hydrolysis of caseins is thought to be more pronounced in cooked cheeses (Sousa et al., 2001; Somers and Kelly, 2002).

Previous investigations have addressed the effect of changing technological variables during different cheese making steps on the action of plasmin, with diverse results. As for $\mathrm{pH}$, it has been studied that $\mathrm{pH}$ values lower than 4.8 at whey draining favored plasmin dissociation from caseins (Grufferty and Fox, 1988), and that high $\mathrm{pH}$ during ripening had great influence in plasmin activity (Voigt et al., 2011). The addition of exogenous plasmin, plasminogen, or plasminogen activators to milk before cheese making has also been applied, with concomitant increase in $\beta$-casein hydrolysis (Upadhyay et al., 2004; Milesi et al., 2008).

Plasmin activity and its influence on cheese proteolysis has been studied in Cheddar-type miniature model cheeses (Watkinson et al., 2001; Somers and Kelly, 2002; Upadhyay et al., 2004; Milesi et al., 2008), in nonripened curds (Choi et al., 2006), and in cheeses made with different technologies at pilot plant scale (Rampilli and Raja, 1998).

As for coagulant, it consists mainly of pure chymosin, which is an aspartic (acid) proteinase (E.C. 3.4.23.4) with a $\mathrm{pH}$ optimum of about 4.0 and a highly specific milk-clotting activity at the $\mathrm{pH}$ of milk (6.7). The residual amount of coagulant enzyme that remains in the curd after whey drainage is up to $15 \%$, as the rest is lost in the whey (Sousa et al., 2001). The retention of coagulant activity in the curd depends on technologi- 
cal factors such as $\mathrm{pH}$ at draining, cooking temperature, and cheese moisture (Jacob et al., 2011). During cheese ripening, the proteolytic action of chymosin on $\alpha_{\mathrm{S} 1}$-casein releases the peptides $\alpha_{\mathrm{S} 1}$ (f1-23) and $\alpha_{\mathrm{S} 1}-\mathrm{I}$ (f24-199); the latter have been seen early in the ripening of soft cheese varieties as they retain large amounts of whey and curd is not scalded (Hynes et al., 2001; Bansal et al., 2007). Some uncertainty exists regarding the extent of inactivation of chymosin in cooked cheeses. It is known that lower amounts of rennet are retained in hard cheeses due to their lower moisture content, and to the denaturation caused by temperature. Despite these facts, inactivation of the coagulant in cooked cheeses has been reported to be partial or reversible (Hayes et al., 2002; Hynes et al., 2004; Costabel et al., 2015).

Ripening of hard cooked cheeses, such as Argentinean Reggianito cheese, is a long process that demands from 6 mo to 2 yr. Little is known about nonmicrobiological enzymes such as plasmin and residual coagulant and their influence on cheese composition.

In a previous study, we validated a new cheese model for Reggianito and other hard cooked cheeses that employs frozen curd and whey and is simpler and less time consuming than standard cheese making (Vélez et al., 2015a); we applied it in the present investigation.

The objective of this work was to assess the effect of $\mathrm{pH}$ at whey drainage, curd scalding temperature, and curd washing on the action of plasmin and residual coagulant enzyme, in a minicurd model. Results were intended to gain scientific knowledge about the effect of technological changes on proteolysis mediated by plasmin and residual coagulant. Innovative cheese-making processes aimed at cheese ripening acceleration as well as control of primary proteolysis are possible examples of further applications.

\section{MATERIALS AND METHODS}

\section{Experimental Design}

The effect of 3 factors on plasmin and coagulant activities and proteolysis was assessed in separate experiments using a new minicurd model. The studied variables were $\mathrm{pH}$ at whey drainage, curd scalding temperature, and the inclusion of a curd washing step. The draining $\mathrm{pH}$ was assayed at 3 levels: 4.6, 5.6, and 6.4 at a cooking temperature fixed at $50^{\circ} \mathrm{C}$. Curd scalding temperature was tested at 2 levels $\left(50\right.$ and $\left.56^{\circ} \mathrm{C}\right)$ maintaining a drain $\mathrm{pH}$ of 5.6. Finally, washing of the curd was tested at 2 levels (absence of washing step, and the replacement of all the whey by water) at a fixed $\mathrm{pH}$ of 5.6 and a curd scalding temperature of $50^{\circ} \mathrm{C}$. The cho- sen ranges for the factors were selected to accentuate the effect of the enzymatic activities in the minicurd model. Besides, ripening time of minicurds was set to 7 $\mathrm{d}$ to use a rapid minicurd model to monitor proteolysis, based on a previous study in which the main effect was observed in the very first stage of ripening (Vélez et al., 2015b).

\section{Minicurd Making}

Minicurds were made according to the model validated by Vélez et al. (2015a). Briefly, raw materials were obtained from a conventional Reggianito Argentino cheese-making in pilot plant. Bulk raw milk (100 L) was obtained from a nearby dairy plant (Milkaut S.A., Santa Fe, Argentina), standardized at $2.8 \%$ of fat, and batch-pasteurized at $65^{\circ} \mathrm{C}$ for $30 \mathrm{~min}$. Starter was a mix of Lactobacillus helveticus and Lactobacillus bulgaricus (Chr. Hansen Argentina, Quilmes, Argentina) added at a concentration of $10^{6} \mathrm{cfu} / \mathrm{mL}$ of milk. Coagulant (Maxiren 150, 100\% chymosin, Gist-Brocades, Seclin, France) was added at a final concentration of $0.012 \mathrm{~g} / \mathrm{L}$ to coagulate the milk. After coagulation and cutting, curd particles and whey were taken from the vat, separated, and stored frozen $\left(-18^{\circ} \mathrm{C}\right)$ until their use for minicurd making. On trial day, the mixture of whey-curd particles $(\sim 500 \mathrm{~g})$ was reconstituted in the appropriate proportion (1:4) from the thawed whey and curds and incubated at $37^{\circ} \mathrm{C}$ until they reached the required $\mathrm{pH}(4.6,5.6$, or 6.4). After that, they were scalded to $45^{\circ} \mathrm{C}$. For the curds in which a washing step was performed, the total volume of whey was replaced by distilled water $\left(\mathrm{pH} 5.5\right.$ at $\left.45^{\circ} \mathrm{C}\right)$. After reaching $45^{\circ} \mathrm{C}$, mixtures were scalded at 50 or $56^{\circ} \mathrm{C}$ according to the treatment. The curds were separated by centrifugation (Multi RF, Thermo Scientific, Waltham, MA) at 2,750 $\times g$ at $37^{\circ} \mathrm{C}$ for $20 \mathrm{~min}$. Minicurds of approximately 25 $\mathrm{g}$ were obtained; they were refrigerated for $5 \mathrm{~min}$ and placed in $20 \%$ (wt/vol) brine at $12^{\circ} \mathrm{C}$ for $20 \mathrm{~min}$. Three replicates trials were carried out, and in each one, 2 minicurds were made in parallel; one was sampled immediately and the other was vacuum packed in a plastic film and stored $7 \mathrm{~d}$ at $12^{\circ} \mathrm{C}$.

\section{Gross Composition}

Minicurds were analyzed in duplicate, as follows: $\mathrm{pH}$, measured by the American Public Health Association method (Bradley et al., 1992); sodium chloride by atomic absorption spectrophotometry (AOAC, 1990); proteins by the Kjeldahl method (IDF, 1993); and moisture content was determined by oven drying to a constant weight at $102 \pm 1^{\circ} \mathrm{C}$ (IDF, 1982). 


\section{Proteolysis Assessment}

Proteolysis was assessed by determination of soluble nitrogen (SN) at $\mathrm{pH} 4.6$, electrophoresis, and peptide profiles, as follows.

\section{Soluble Nitrogen at pH 4.6 (SN 4.6)}

The nitrogen content was determined by Kjeldahl method, and the values were expressed as percentage of total nitrogen (TN; Hynes et al., 2001).

\section{Electrophoresis}

The insoluble residue at $\mathrm{pH} 4.6$ was analyzed by urea-PAGE in a Mini-Protean II cube (Bio-Rad Laboratories, Hercules, CA) by the Andrews (1983) method, with a concentration of acrylamide of $7.5 \%$ (Hynes et al., 1999). Proteins were stained by Coomassie Blue G-250.

\section{Peptide Analysis by Reverse-Phase HPLC}

Water-soluble extracts of minicurds were obtained by blending $5 \mathrm{~g}$ of cheese and $15 \mathrm{~mL}$ of distilled water with mortar and pestle, warmed up to $40^{\circ} \mathrm{C}$, and maintained for $1 \mathrm{~h}$. The suspension was centrifuged at $3,000 \times$ $g$, $30 \mathrm{~min}$, and filtered through fast flow filter paper and adjusted to a final volume of $25 \mathrm{~mL}$. Samples were filtered through 0.45- $\mu \mathrm{m}$ membranes (Millex, Millipore, Saõ Paulo, Brazil), and injected into the HPLC chromatograph (Series 200, Perkin Elmer, Norwalk, CT). Separation was achieved on a $220 \times 4.6 \mathrm{~mm}$ Aquapore OD-300 C18, 5 mm-300 $\mathrm{A}^{\circ}$ analytical column (Perkin Elmer) under an increasing linear gradient of acetonitrile in water, over $107 \mathrm{~min}$, according to Bergamini et al. (2006). Detection was performed at $214 \mathrm{~nm}$, column temperature was $40^{\circ} \mathrm{C}$, and flow rate was $1 \mathrm{~mL} \cdot \mathrm{min}^{-1}$.

\section{Microbial Counts}

The population of total thermophilic lactic flora present in minicurds was determined by plating sample dilutions on skim milk agar (SMA) and counting plate colonies after $48 \mathrm{~h}$ of incubation at $37^{\circ} \mathrm{C}$ according to American Public Health Association standards (Frank et al., 1993).

\section{Plasmin and Plasminogen-Derived Activities}

The plasmin activity and plasminogen-derived activity were determined according to the method described by Richardson and Pearce (1981). Plasminogen was determined after addition of urokinase as an activator (Rampilli and Raja, 1998). Both enzyme activities in samples were normalized to DM of minicurds, as results were expressed in 7-amino-4-methyl coumarin units: nanomoles of 7-amino-4-methyl coumarin released per minute per gram of minicurd (DM).

\section{Residual Coagulant Activity}

Residual coagulant activity in cheese samples was analyzed using the method described in Costabel et al. (2015). The activity was expressed as the nanomoles of product [tripeptide $\left(\mathrm{NO}_{2}\right.$-Phe)-Arg-Leu] released by coagulant per hour per gram of dried minicurd.

\section{Statistical Analysis}

One-way ANOVA was applied on composition, proteolysis, and enzyme activities data for each experience. The influence of time was also checked for each parameter.

\section{RESULTS}

\section{Gross Composition and Microbial Counts}

Minicurd composition (moisture and protein content) was similar for all minicurds made at different $\mathrm{pH}$ and cooking temperatures, but washed minicurds had higher moisture than nonwashed ones, which was significantly shown at $7 \mathrm{~d}$. Accordingly, washed minicurds showed higher salt content than the others (Table 1).

As for $\mathrm{pH}$, the values remained constant during the $7 \mathrm{~d}$ of storage when whey was drained at $\mathrm{pH} 5.6$ and 4.6 , whereas the $\mathrm{pH}$ of minicurds drained at 6.4 decreased significantly $(P<0.05)$. Starting from similar $\mathrm{pH}$ values, curd-washed samples showed significantly $(P<0.05)$ higher $\mathrm{pH}$ than their controls at $7 \mathrm{~d}$. Curd scalding temperature, on the other hand, did not affect the $\mathrm{pH}$.

The counts of total thermophilic lactic acid bacteria reached $10^{8} \mathrm{cfu} / \mathrm{g}$ in all minicurds immediately after preparation, with no differences between treatments.

\section{Plasmin/Plasminogen Activity}

Draining $\mathrm{pH}$ and curd washing were the technological factors that showed an influence on plasmin activity at both 0 and $7 \mathrm{~d}$ (Table 2).

When whey was drained at $\mathrm{pH} 4.6$ and 5.6, plasmin activity in the minicurds was similar and significantly $(P<0.05)$ lower than in minicurds drained at $\mathrm{pH} 6.4$. As for the washing step, it increased the net plasmin 


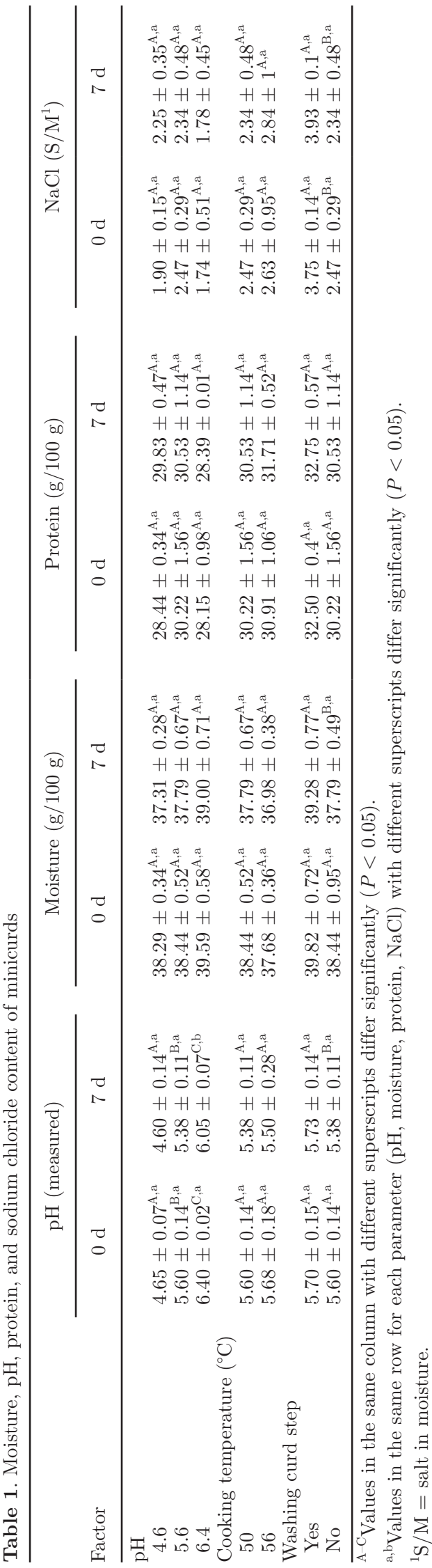

activity in comparison with the nonwashed minicurds $(P<0.05)$. Scalding temperature had no effect on plasmin activity. On the other hand, the activity of plasmin did not change during storage of the minicurds for all the treatments assayed.

The $\mathrm{pH}$ of whey draining had a similar effect on plasminogen, the inactive precursor of plasmin, than on the active enzyme; plasminogen values at $\mathrm{pH} 5.6$ and 4.6 were similar between them and lower than at 6.4 . However, this effect was only verified at $d$, whereas at d 0 no differences were found. Similarly, the scalding temperature had no effect on plasminogen level, with the sole exception of a significant $(P<0.05)$ decrease of the precursor activity observed during storage of $56^{\circ} \mathrm{C}$ scalded curds.

\section{Residual Coagulant Activity}

Coagulant activity in minicurds at 0 and $7 \mathrm{~d}$ of storage is shown in Table 3. Changes in draining $\mathrm{pH}$ affected the enzyme activity at the 2 times studied in the same way. The lowest levels were detected in minicurds made at $\mathrm{pH} 6.4$, whereas minicurds of $\mathrm{pH} 4.6$ and 5.6 had the highest and intermediate levels, respectively. Besides, in minicurds drained at $\mathrm{pH} 5.6$ and 6.4, the activity increased significantly during storage.

Scalding temperature had a negative effect on coagulant activity, as minicurds cooked at $50^{\circ} \mathrm{C}$ had the highest activity throughout storage. In addition, under both treatments, the enzyme activity increased significantly from 0 to $7 \mathrm{~d}$. Finally, washing the curd did not show an influence on coagulant activity. However, chymosin activity in the minicurds significantly increased during storage in which a washing step was not performed.

\section{Soluble Nitrogen at pH 4.6 and Electrophoresis}

Whey drainage at $\mathrm{pH} 4.6$ and curd washing had a positive effect on proteolysis of the minicurds evidenced by an increase in $\mathrm{SN}-\mathrm{pH} 4.6 / \mathrm{TN}$ from 0 to $7 \mathrm{~d}(P \leq$ $0.05)$. In all the other cases, $\mathrm{SN}-\mathrm{pH} 4.6 / \mathrm{TN}$ neither was significantly different among treatments nor changed with storage time (Table 4).

Figure 1 displays the electrophoresis urea-PAGE of minicurds from all treatments. One example is given for each trial. No influence of the experimental treatment was observed on plasmin-mediated proteolysis of $\beta$-casein to $\gamma$-caseins. On the contrary, decreasing $\mathrm{pH}$ showed an effect on the proteolytic action of chymo$\sin$, as observed by $\alpha_{\mathrm{S}_{1}}$-casein degradation to $\alpha_{\mathrm{S} 1}-\mathrm{I}-\mathrm{CN}$

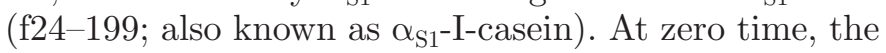
band that corresponds to $\alpha_{\mathrm{S} 1}$-I-casein could be observed in minicurds drained at $\mathrm{pH} 4.6$ (lane 2), which was not noticeable in curds drained at $\mathrm{pH} 5.6$ or 6.4 . After $7 \mathrm{~d}$ 
Table 2. Plasmin and plasminogen activities (nmol of 7-amino-4-methyl coumarin released $\mathrm{min}^{-1} \cdot \mathrm{g}^{-1}$ on a DM basis) during storage of minicurds

\begin{tabular}{|c|c|c|c|c|}
\hline \multirow[b]{2}{*}{ Factor } & \multicolumn{2}{|c|}{ Plasmin activity } & \multicolumn{2}{|c|}{ Plasminogen activity } \\
\hline & $0 \mathrm{~d}$ & $7 \mathrm{~d}$ & $0 \mathrm{~d}$ & $7 \mathrm{~d}$ \\
\hline \multicolumn{5}{|l|}{$\overline{\mathrm{pH}}$} \\
\hline 4.6 & $3.82 \pm 0.2^{\mathrm{A}, \mathrm{a}}$ & $3.66 \pm 0.26^{\mathrm{A}, \mathrm{a}}$ & $1.97 \pm 0.20^{\mathrm{A}, \mathrm{a}}$ & $1.32 \pm 0.26^{\mathrm{A}, \mathrm{a}}$ \\
\hline 5.6 & $4.91 \pm 0.58^{\mathrm{A}, \mathrm{a}}$ & $4.99 \pm 0.50^{\mathrm{A}, \mathrm{a}}$ & $2.52 \pm 0.72^{\mathrm{A}, \mathrm{a}}$ & $1.93 \pm 0.30^{\mathrm{A}, \mathrm{c}}$ \\
\hline 6.4 & $7.14 \pm 0.81^{\mathrm{B}, \mathrm{a}}$ & $8.98 \pm 1.04^{\mathrm{B}, \mathrm{a}}$ & $2.57 \pm 0.03^{\mathrm{A}, \mathrm{a}}$ & $2.84 \pm 0.11^{\mathrm{B}, \mathrm{a}}$ \\
\hline \multicolumn{5}{|c|}{ Cooking temperature $\left({ }^{\circ} \mathrm{C}\right)$} \\
\hline 50 & $4.91 \pm 0.58^{\mathrm{A}, \mathrm{a}}$ & $4.99 \pm 0.50^{\mathrm{A}, \mathrm{a}}$ & $2.52 \pm 0.72^{\mathrm{A}, \mathrm{a}}$ & $1.93 \pm 0.30^{\mathrm{A}, \mathrm{C}}$ \\
\hline 56 & $5.10 \pm 0.42^{\mathrm{A}, \mathrm{a}}$ & $4.03 \pm 0.50^{\mathrm{A}, \mathrm{a}}$ & $2.50 \pm 0.25^{\mathrm{A}, \mathrm{a}}$ & $1.09 \pm 0.31^{\mathrm{A}, \mathrm{I}}$ \\
\hline \multicolumn{5}{|c|}{ Washing step } \\
\hline Yes & $8.05 \pm 1.29^{\mathrm{A}, \mathrm{a}}$ & $8.88 \pm 0.65^{\mathrm{A}, \mathrm{a}}$ & $2.13 \pm 0.85^{\mathrm{A}, \mathrm{a}}$ & $2.59 \pm 0.40^{\mathrm{A}, \mathrm{c}}$ \\
\hline No & $4.91 \pm 0.58^{\mathrm{B}, \mathrm{a}}$ & $4.99 \pm 0.50^{\mathrm{B}, \mathrm{a}}$ & $2.52 \pm 0.72^{\mathrm{A}, \mathrm{a}}$ & $1.93 \pm 0.30^{\mathrm{A}, \mathrm{a}}$ \\
\hline
\end{tabular}

$\overline{\mathrm{A}, \mathrm{B}}$ For each experience, values in the same column with different superscripts differ significantly $(P<0.05)$.

${ }^{\mathrm{a}, \mathrm{b}}$ For each enzymatic activity, values in the same row with different superscripts differ significantly $(P<0.05)$.

of storage, the peptide was observed in minicurds of $\mathrm{pH}$ 4.6 and 5.6 (lanes 5 and 6 ), whereas no hydrolysis was verified at $\mathrm{pH} 6.4$ (lane 4 ).

As for curd scalding temperature, at $0 \mathrm{~d}$ no differences were observed (lanes 3 and 7 ), but at $7 \mathrm{~d}$, minicurds that were scalded at $50^{\circ} \mathrm{C}$ (lane 6) had a stronger band of $\alpha_{\mathrm{S} 1}-\mathrm{I}-\mathrm{CN}$ than those cooked at $56^{\circ} \mathrm{C}$ (lane 9). Washing the curd did not significantly affect the $\alpha_{S_{1}}$-casein hydrolysis. At $0 \mathrm{~d}$, the intensity of the $\alpha_{S 1-}$-I-casein band was slightly weaker in the minicurds made in the absence of a washing step (lane 3) with respect to the washed ones (lane 8), and at $7 \mathrm{~d}$ no differences were found (lanes 6 and 10).

\section{Peptide Profiles}

The peptide profiles of water-soluble fractions of minicurds drained at different $\mathrm{pH}$ were different (Fig-

Table 3. Coagulant activity (nmol of product $\mathrm{h}^{-1} \cdot \mathrm{g}^{-1}$ on a DM basis) during storage of minicurds

\begin{tabular}{|c|c|c|}
\hline \multirow[b]{2}{*}{ Factor } & \multicolumn{2}{|c|}{ Coagulant activity } \\
\hline & $0 \mathrm{~d}$ & $7 \mathrm{~d}$ \\
\hline \multicolumn{3}{|l|}{$\mathrm{pH}$} \\
\hline 4.6 & $177.0 \pm 10.28^{\mathrm{A}, \mathrm{a}}$ & $220.3 \pm 24.43^{\mathrm{A}, \mathrm{a}}$ \\
\hline 5.6 & $137.3 \pm 3.98^{\mathrm{B}, \mathrm{a}}$ & $181.7 \pm 7.84^{\mathrm{A}, \mathrm{b}}$ \\
\hline 6.4 & $60.3 \pm 3.37^{\mathrm{C}, \mathrm{a}}$ & $79.3 \pm 10.52^{\mathrm{B}, \mathrm{b}}$ \\
\hline \multicolumn{3}{|c|}{ Cooking temperature $\left({ }^{\circ} \mathrm{C}\right)$} \\
\hline 50 & $137.3 \pm 3.98^{\mathrm{A}, \mathrm{a}}$ & $181.7 \pm 7.84^{\mathrm{A}, \mathrm{b}}$ \\
\hline 56 & $93.6 \pm 2.92^{\mathrm{B}, \mathrm{a}}$ & $125.5 \pm 0.89^{\mathrm{B}, \mathrm{b}}$ \\
\hline \multicolumn{3}{|c|}{ Washing step } \\
\hline Yes & $113.5 \pm 23.56^{\mathrm{A}, \mathrm{a}}$ & $138.0 \pm 21.95^{\mathrm{A}, \mathrm{a}}$ \\
\hline No & $135.0 \pm 1.61^{\mathrm{A}, \mathrm{a}}$ & $166.6 \pm 1.61^{\mathrm{A}, \mathrm{b}}$ \\
\hline
\end{tabular}

${ }^{\mathrm{A}-\mathrm{C}}$ For each experience, values in the same column with different superscripts differ significantly $(P<0.05)$.

${ }^{\mathrm{a}, \mathrm{b}}$ Values in the same row with different superscripts differ significantly $(P<0.05)$ ure 2). For minicurds drained at $\mathrm{pH} 6.4$, the main peaks of the chromatogram were found toward the end of the profile (in the region of retention time 65-80 min). On the contrary, for minicurds drained at $\mathrm{pH} 4.6$ and 5.6, the main peaks were at the beginning of the profile, between 5 and $60 \mathrm{~min}$. Quantitative differences were found between minicurds drained at 4.6 and 5.6, with higher peptidolysis in the first. In all minicurds, the profiles showed an increase of the main peaks during storage.

The peptide profiles were also affected by cooking temperature (Figure 3), and the differences were seen mainly in the interval comprised between 5 and 60 min. The peak areas that eluted at times up to $55 \mathrm{~min}$ were superior in the minicurds cooked at $50^{\circ} \mathrm{C}$; and the increase in the peak areas during storage was more significant for $50^{\circ} \mathrm{C}$-scalded minicurds.

Table 4. Content of soluble nitrogen (SN)-pH 4.6/total nitrogen (TN) at 0 and $7 \mathrm{~d}$ of storage

\begin{tabular}{lcc}
\hline & \multicolumn{2}{c}{$\mathrm{SN}-\mathrm{pH} 4.6 / \mathrm{TN}(\%)$} \\
\cline { 2 - 3 } Factor & \multicolumn{1}{c}{$0 \mathrm{~d}$} & $7 \mathrm{~d}$ \\
\hline $\mathrm{pH}$ & $5.17 \pm 0.24^{\mathrm{A}, \mathrm{a}}$ & $6.74 \pm 0.34^{\mathrm{A}, \mathrm{b}}$ \\
4.6 & $4.83 \pm 0.91^{\mathrm{A}, \mathrm{a}}$ & $5.98 \pm 1.26^{\mathrm{A}, \mathrm{a}}$ \\
5.6 & $4.23 \pm 0.40^{\mathrm{A}, \mathrm{a}}$ & $5.84 \pm 0.95^{\mathrm{A}, \mathrm{a}}$ \\
6.4 & $4.83 \pm 0.91^{\mathrm{A}, \mathrm{a}}$ & $5.98 \pm 0.91^{\mathrm{A}, \mathrm{a}}$ \\
Cooking temperature $\left({ }^{\circ} \mathrm{C}\right)$ & $3.81 \pm 0.75^{\mathrm{A}, \mathrm{a}}$ & $4.89 \pm 0.50^{\mathrm{A}, \mathrm{a}}$ \\
50 & $3.99 \pm 0.58^{\mathrm{A}, \mathrm{a}}$ & $7.02 \pm 1.10^{\mathrm{A}, \mathrm{b}}$ \\
56 & $4.83 \pm 0.91^{\mathrm{A}, \mathrm{a}}$ & $5.98 \pm 0.91^{\mathrm{A}, \mathrm{a}}$ \\
Washing step & & \\
Yes & \\
No & \\
A,B For each experience, values in the same column with different super- \\
scripts differ significantly $(P<0.05)$. \\
${ }^{\mathrm{a}, \mathrm{b}}$ Values in the same row with different superscripts differ significantly \\
$(P<0.05)$.
\end{tabular}



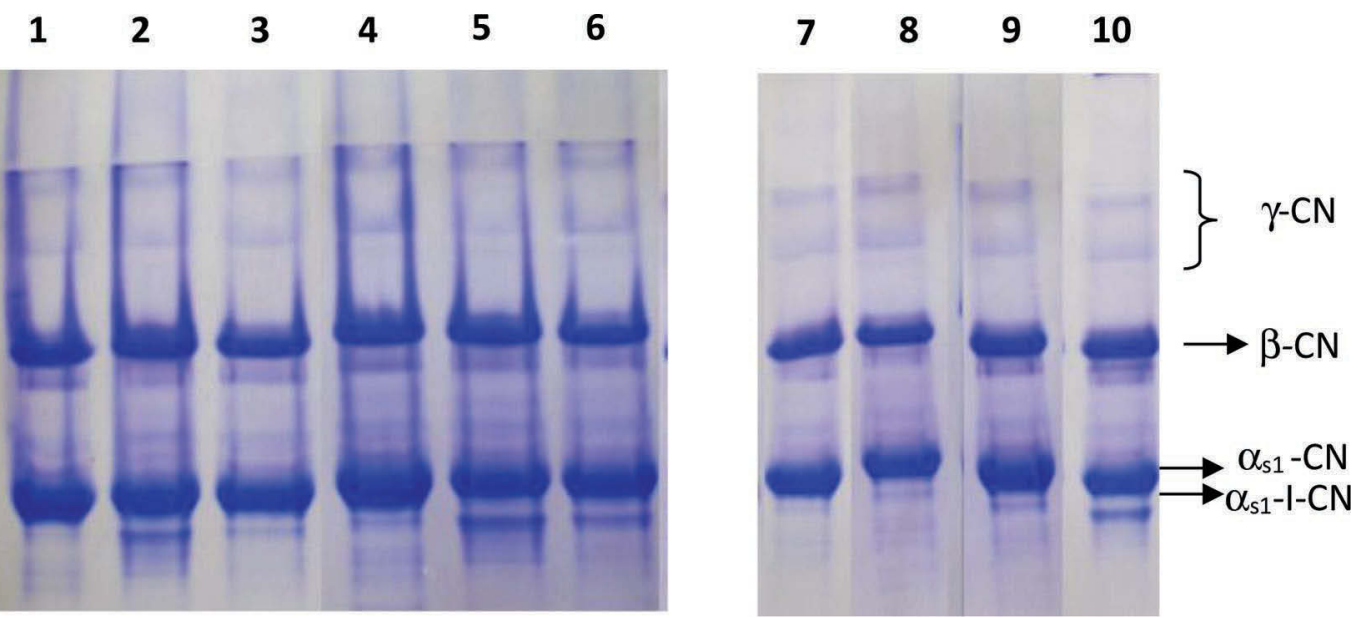

Figure 1. Urea-PAGE electrophoretograms of minicurds. One replicate is shown as an example. Lanes 1, 2, and 3: minicurds at 0 d, cooking temperature $50^{\circ} \mathrm{C}$, drained at $\mathrm{pH} 6.4,4.6$, and 5.6. Lanes 4,5 , and 6 : minicurds at $7 \mathrm{~d}$, cooking temperature $50^{\circ} \mathrm{C}$, drained at $\mathrm{pH} 6.4,4.6$, and 5.6. Lanes 7 and 9: minicurds at 0 and $7 \mathrm{~d}$, cooking temperature $56^{\circ} \mathrm{C}$, drained at $\mathrm{pH} 5.6$. Lanes 8 and 10 : minicurds at 0 and $7 \mathrm{~d}$, cooking temperature $50^{\circ} \mathrm{C}$, drained at $\mathrm{pH} 5.6$, with a washing step. Color version available online.

At the beginning of storage, curds with a washing step showed diminished peak areas, possibly as a consequence of losing soluble peptides (Figure 4). However, during storage, minicurds with or without a washing step experienced an increase in the area of the peaks, reaching similar levels for both treatments. Unlike curds without a washing step, the washed curds also showed an increase in the area of the peaks eluted at retention times between 65 and 80 min.

\section{DISCUSSION}

Protein and moisture content of minicurds were similar to those obtained by Vélez et al. (2015a) for validation of this minicurd model. Moisture was comparable to the value found in young Reggianito cheese (Sihufe et al., 2007). All minicurds had similar moisture and protein contents, regardless of the changes in technology introduced by the experimental design. Increasing

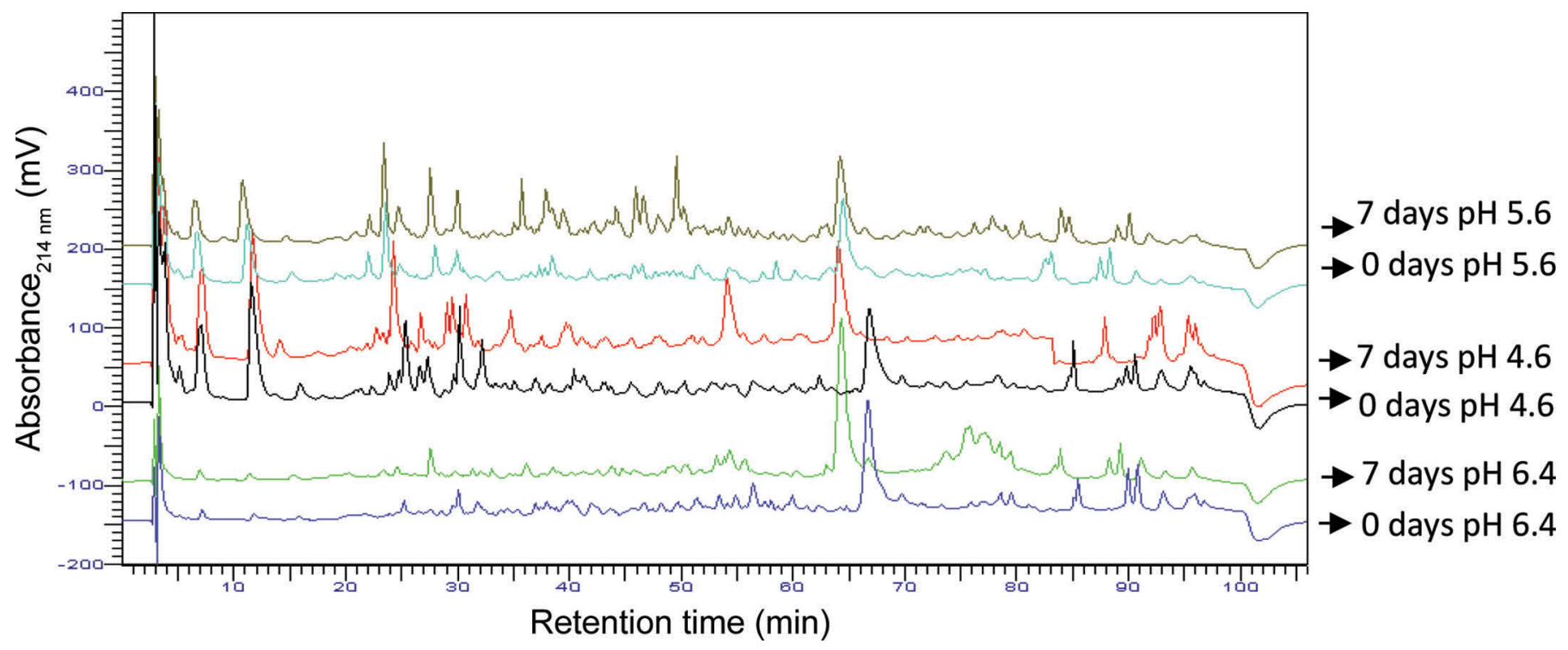

Figure 2. Reverse-phase HPLC chromatograms of water-soluble extracts of minicurds made at $\mathrm{pH} 4.6,5.6$, and 6.4 , all at 0 and $7 \mathrm{~d}$ of storage. Color version available online. 


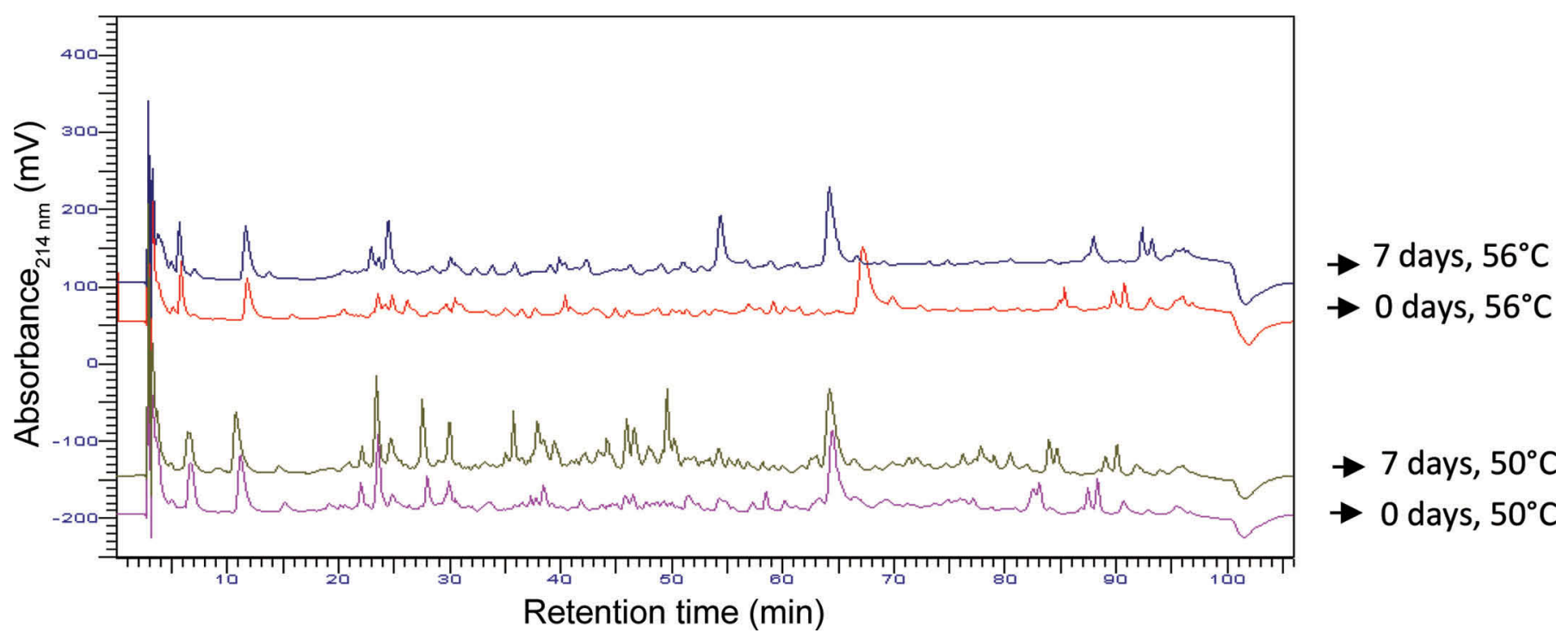

Figure 3. Reverse-phase HPLC chromatograms of water-soluble extracts of minicurds made at 50 and $56^{\circ} \mathrm{C}$, all at 0 and $7 \mathrm{~d}$ of storage. Color version available online.

cooking temperature and lowering $\mathrm{pH}$ did not diminish moisture content, showing that the curd making was robust to compositional changes. In this sense, the model was adequate to study the effect of enzymatic mediated proteolysis without the influence of significant changes in curds moisture content. Meanwhile, a slight but significant difference was found in washed minicurds at $\mathrm{d}$ 7. This was not expected because curd washing has been reported as not changing gross composition in cheeses where technology was modified to study this technological parameter (Moatsou et al., 2004; Shakeel-
Ur-Rehman et al., 2004; Hou et al., 2012). No previous reports in high-cooking temperature cheeses were found.

Accordingly, chloride content increased in washed minicurds most likely due to the increased salt uptake (Fox et al., 2000).

In most minicurds, $\mathrm{pH}$ remained constant, as only those drained at $\mathrm{pH} 6.4$ showed significant acidification during storage, probably due to the higher content of available lactose for starter fermentation. Accordingly, an influence on $\mathrm{pH}$ was detected for the washing step

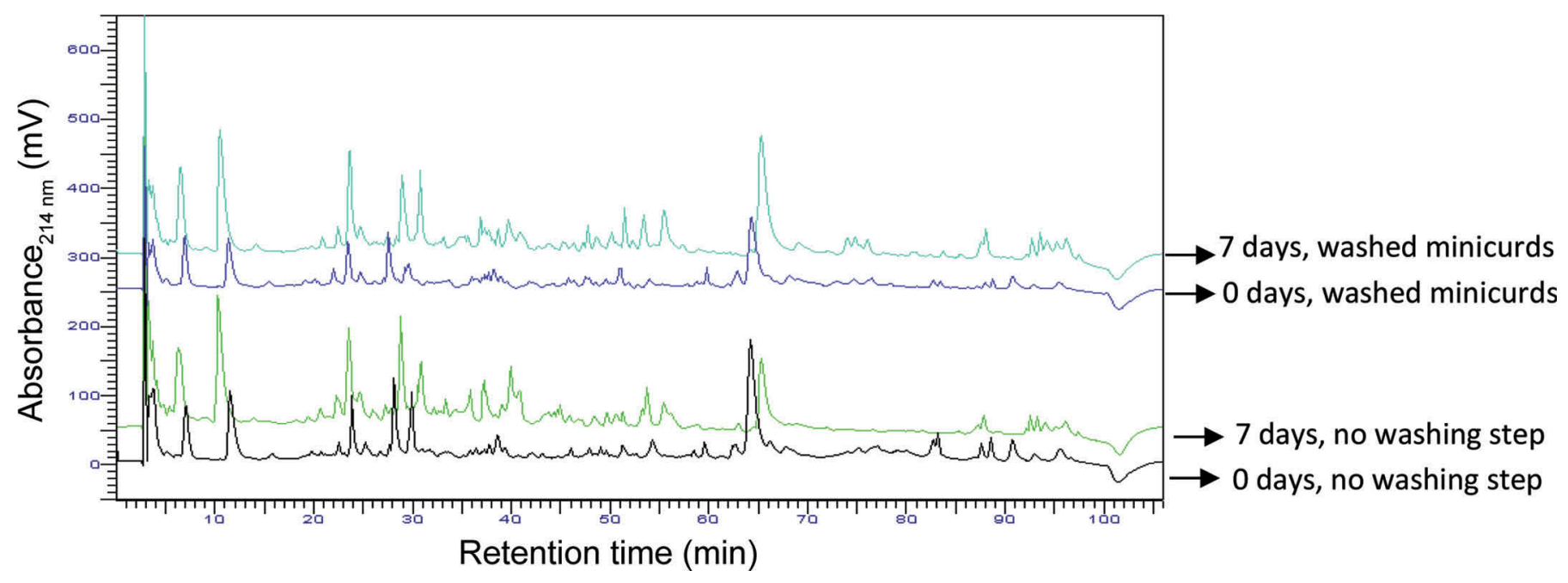

Figure 4. Reverse-phase HPLC chromatograms of water-soluble extracts of minicurds made in the presence and absence of a washing step, all at 0 and $7 \mathrm{~d}$ of storage. Color version available online. 
as $\mathrm{pH}$ values were higher in 7 -d-old washed minicurds, in which whey was replaced by water, reducing lactose content. Washing of the curd is traditional in fresh, acid cheeses (for example, cottage cheeses) and in Gouda cheeses with the purpose of removing lactose and lactic acid, but it is not applied in Italian hard type cheeses where its influence is not known.

The SN increased significantly during storage of minicurds only for those drained at $\mathrm{pH} 4.6$ and washed; as it will be pointed later, this effect can be attributed mainly to the action of the coagulant and plasmin, respectively. For the rest of the minicurds, the SN remained constant during the short time they were kept. Average SN 4.6/TN was 5\%, which is within the range for young Reggianito cheeses (Candioti et al., 2002).

When the SN of minicurds at the same time of storage was compared, significant differences among treatments were not found. Technological changes on cheese making, such as different starter strains (Candioti et al., 2002), increasing cooking temperatures (Hayaloglu et al., 2010), or whey draining $\mathrm{pH}$ (Watkinson et al., 2001), may cause only small modifications on $\mathrm{SN}$ at $\mathrm{pH}$ 4.6 in young cheeses, or not be detected by this index at all. Indeed, $\mathrm{SN}$ at $\mathrm{pH} 4.6$ is a nonspecific index that represents mainly proteins (except caseins), medium-sized peptides derived from casein hydrolysis, and proteose peptone fraction composed mainly from the N-terminal fragments of $\beta$-casein, produced by plasmin cleavage; it also contains nonprecipitated whey proteins and small peptides, free AA, and smaller $\mathrm{N}$ compounds, such as amines, urea, and ammonium (Ardö, 1999).

Plasmin activity increased with increasing $\mathrm{pH}$, with values significantly higher at $\mathrm{pH} 6.4$ than at $\mathrm{pH} 4.6$ and 5.6. Our results agree with others that report that $\beta$-casein is more rapidly hydrolyzed in Swiss cheeses than in Cheddar or Gouda, attributing this fact to the higher $\mathrm{pH}$ values of the first type of cheeses (Fox et al., 1993). In mold-ripened cheeses, $\mathrm{pH}$ can be higher than 7 , the action of plasmin being a major contribution to primary proteolysis (Voigt et al., 2011). According to our results, the highest plasmin activity at $\mathrm{pH} 6.4$ was concomitant with an increase in the proteolysis described by peptide profiles. There was an increase in the peak areas that have been recognized as characteristic products of plasmin (Kelly and O'Donnell, 1998; Upadhyay et al., 2004). No increase on $\gamma$ casein production assessed by electrophoresis was detected.

The $\mathrm{pH}$ did not affect plasminogen activity in minicurds at zero days, but at $\mathrm{d} 7$, the minicurds drained at $\mathrm{pH} 6.4$ had higher activity of the precursor than the curds drained at $\mathrm{pH} 4.6$ and 5.6. This fact could indicate some type of plasminogen denaturation at low $\mathrm{pH}$, as no passage of the precursor to the active enzyme was concomitantly shown. There are some reports about the adverse effect of lowering the $\mathrm{pH}$ on plasminogen retention in the curd and its activity (Crudden and Kelly, 2003).

For minicurds scalded at $56^{\circ} \mathrm{C}$, plasminogen activity decreased with time of storage; also, in this case such result did not correlate with an increase in plasmin activity, which indicated that no activation of the precursor occurred. At the 2 times studied, cooking temperature did not affect plasmin and plasminogen activity significantly; neither electrophoresis nor peptide profiles showed evidence of changes in plasmin activity. These results did not match those obtained by Richardson and Pearce (1981), Rampilli and Raja (1998), and Somers and Kelly (2002). The disagreement is probably due to the age of the cheeses studied by the mentioned authors.

In the present work, washing of the curd increased plasmin activity, an observation that can likely be attributed to the elimination of plasmin inhibitors with the whey (Guinee and Fox, 2004). Higher plasmin activity correlated with increasing peak areas of hydrophobic peptides. As far as we know, no previous reports about the effect of curd washing on plasmin activity are available, although few investigations have attributed the relatively high plasmin activity in Gouda and Pategrás Argentino cheeses to the washing step (Grufferty and Fox, 1988; Fox et al., 1993; Vélez et al., 2015b).

As for coagulant, low whey draining $\mathrm{pH}$ (4.6 and 5.6) increased its activity. Similar results were found by Bansal et al. (2007), who found that draining the whey at $\mathrm{pH}$ below 5.7 increased retention of the enzyme, determined by measuring its activity.

The variation found in the chymosin activity correlated with $\alpha_{S 1}$-casein hydrolysis evidenced by electrophoresis and with an increase of the peak areas of the initial zone of the soluble peptide profile. In this sense, Bansal et al. (2007) and Milesi et al. (2008) reported that higher areas of peaks at the beginning of the peptide profile $(5-60 \mathrm{~min})$ derived from increased coagulant activity.

Chymosin activity was also enhanced by decrease in curd scalding temperature, which was confirmed by electrophoresis and the peptide profiles. The highest effect was seen at $7 \mathrm{~d}$ of storage. In this sense, Hynes et al. (2004) and Sheehan et al. (2007) found a reactivation of chymosin after curd cooking, which was described during ripening.

Finally, washing the curd did not indicate a significant influence either in chymosin activity or its products of proteolysis. 


\section{CONCLUSIONS}

The increase of $\mathrm{pH}$ at whey draining and the washing of the curd had a positive effect on plasmin activity and increased its action on proteolysis, which was evidenced by soluble peptide profiles. No effect of the curd scalding temperature was observed on plasmin activity. The treatments studied in the present work did not indicate plasminogen activation during $7 \mathrm{~d}$ of ripening. As for coagulant, lower $\mathrm{pH}$ values at whey draining and a decrease in curd cooking temperature increased its activity; washing of the curd had no significant influence on chymosin. These results were consistent with the proteolysis enhancement detected by peptide profiles, electrophoresis, and nitrogen fractions.

\section{ACKNOWLEDGMENTS}

The authors acknowledge CONICET (Consejo Nacional de Investigaciones Científicas y Técnicas, Argentina) for the fellowship of M. Ayelén Vélez. The present work was financially supported by UNL (Universidad Nacional del Litoral, Argentina) and ANPCyT (Agencia Nacional de Promoción Científica y Tecnológica, Argentina).

\section{REFERENCES}

Andrews, A. T. 1983. Proteinases in normal bovine milk and their action on caseins. J. Dairy Res. 50:45-55.

AOAC. 1990. Official Methods of Analysis of Association of Official Analytical Chemists. Vol. II. AOAC, Arlington, VA.

Ardö, Y. 1999. Evaluating proteolysis by analyzing the N content of cheese fraction. Pages 4-9 in Bulletin IDF 337: Chemical Methods for Evaluating Proteolysis in Cheese Maturation (Part 2). Y. Ardö, ed. International Dairy Federation, Brussels, Belgium.

Bansal, N., P. F. Fox, and P. L. H. McSweeney. 2007. Factors affecting the retention of rennet in cheese curd. J. Agric. Food Chem. 55:9219-9225.

Bergamini, C. V., E. Hynes, and C. A. Zalazar. 2006. Influence of probiotic bacteria in the proteolysis profile of a semi-hard cheese. Int. Dairy J. 16:856-866.

Bradley, R., Jr., E. Arnold, D. Barbano, R. Semerad, D. Smith, and B. Vines. 1992. Chemical and physical methods. Pages 433-532 in Standard Methods for the Examination of Dairy Products. R. Marshall, ed. American Public Health Association (APHA), Washington, DC.

Candioti, M. C., E. R. Hynes, A. Quiberoni, S. B. Palma, N. Sabbag, and C. A. Zalazar. 2002. Reggianito Argentino cheese: Influence of Lactobacillus helveticus strains isolated from natural whey cultures on cheese making and ripening processes. Int. Dairy J. 12:923-931.

Choi, L. H., L. M. Were, and S. Nielsen. 2006. Effects of incubation temperature and salt concentration on plasminogen activators in cheese curd. Int. Dairy J. 16:609-618.

Costabel, L. M., C. V. Bergamini, L. Pozza, F. Cuffia, M. C. Candioti, and E. Hynes. 2015. Influence of chymosin type and curd scalding temperature on proteolysis of hard cooked cheeses. J. Dairy Res. $82: 375-384$.

Crudden, A., and A. Kelly. 2003. Studies of plasmin activity in whey. Int. Dairy J. 13:987-993.
Fox, P. F., T. P. Guinee, T. M. Cogan, and P. L. H. McSweeney. 2000. Salting of cheese curd. Pages 153-167 in Fundamentals of Cheese Science. P. F. Fox, T. Guinee, T. Cogan, and P. L. H. McSweeney, eds. Aspen Publishers Inc., Gaithersburg, MD.

Fox, P. F., J. Law, P. L. H. McSweeney, and J. Wallace. 1993. Biochemistry of Cheese Ripening. Pages 389-438 in Cheese: Chemistry, Physics and Microbiology. Vol. 1. P. F. Fox, ed. Chapman \& Hall, London, UK.

Frank, J., G. Christen, and L. Bullerman. 1993. Test for groups of microorganism. Pages 271-286 in Standard Methods for the Examination of Dairy Products. R. Marshall, ed. American Public Health Association (APHA), Washington, DC.

Grufferty, M. B., and P. Fox. 1988. Milk alkaline protease. J. Dairy Res. 55:609-630.

Guinee, T. P., and P. F. Fox. 2004. Salt in Cheese: Physical, Chemical and Biological Aspects. Pages 207-259 in Cheese Chemistry, Physics and Microbiology. General Aspects. 3rd ed. Vol. 1. P. F. Fox, P. L. H. McSweeney, T. M. Cogan, and T. P. Guinee, ed. Elsevier Academic Press, London, UK.

Hayaloglu, A. A., K. C. Deegan, and P. L. H. McSweeney. 2010. Effect of milk pasteurization and curd scalding, temperature on proteolysis in Malatya, a Halloumi-type cheese. Dairy Sci. Technol. 90:99-109.

Hayes, M. G., J. C. Oliveira, P. L. H. McSweeney, and A. L. Kelly. 2002. Thermal inactivation of chymosin during cheese manufacture. J. Dairy Res. 69:269-279.

Hou, J., J. A. Hannon, P. L. H. McSweeney, T. P. Beresford, and T. P. Guinee. 2012. Effect of curd washing on composition, lactose metabolism, $\mathrm{pH}$, and the growth of non-starter lactic acid bacteria in full-fat Cheddar cheese. Int. Dairy J. 25:21-28.

Hynes, E., L. Aparo, and M. C. Candioti. 2004. Influence of residual milk-clotting enzyme on $\alpha_{\mathrm{S1}^{-}}$-casein hydrolysis during ripening of Reggianito Argentino cheese. J. Dairy Sci. 87:565-573.

Hynes, E., A. Delacroix-Buchet, C. A. Meinardi, and C. A. Zalazar. 1999. Relation between $\mathrm{pH}$, degree of proteolysis and consistency in soft cheese. Aust. J. Dairy Technol. 54:24-27.

Hynes, E., A. Delacroix-Buchet, and C. A. Zalazar. 2001. Influence of milk-clotting enzyme in proteolysis during ripening of Cremoso Argentino cheese. Aust. J. Dairy Technol. 56:208-212.

IDF (International Dairy Federation). 1982. Standard 4A: Cheese and processed cheese: Determination of the total solids content. Reference method. IDF, Brussels, Belgium.

IDF (International Dairy Federation). 1993. Standard 20B: Milk: Determination of nitrogen content by Kjeldahl method. Reference Method. IDF, Brussels, Belgium.

Jacob, M., D. Jaros, and H. Rohm. 2011. Recent advances in milk clotting enzymes. Int. J. Dairy Technol. 64:14-33.

Kelly, A. L., and H. J. O'Donnell. 1998. Composition, gel properties and microstructure of Quarg as affected by processing parameters and milk quality. Int. Dairy J. 8:295-301.

Milesi, M. M., P. L. H. McSweeney, and E. Hynes. 2008. Viability and contribution to proteolysis of an adjunct culture of Lactobacillus plantarum in two model cheese systems: Cheddar cheese-type and soft-cheese type. J. Appl. Microbiol. 105:884-892.

Moatsou, G., E. Moschopoulou, and E. Anifantakis. 2004. Effect of different manufacturing parameters on the characteristics of Graviera Kritis cheese. Int. J. Dairy Tech. 4:215-220.

Rampilli, M., and V. Raja. 1998. Osservazioni sull'atti-vitá di plasmina e plasminogeno nel formaggio. Sci. Tec. Latt. Cas. 49:341-350.

Richardson, B. C., and K. N. Pearce. 1981. The determination of plasmin in dairy products. N.Z. J. Dairy Sci. Tech. 16:209-220.

Shakeel-Ur-Rehman, D. Waldron, and P. F. Fox. 2004. Effect of modifying lactose concentration in cheese curd on proteolysis and in quality of Cheddar cheese. Int. Dairy J. 14:591-597.

Sheehan, J. J., J. C. Oliveira, A. L. Kelly, and P. L. H. Mc Sweeney. 2007. Effect of cook temperature on primary proteolysis and predicted residual chymosin activity of a semi-hard cheese manufactured using thermophilic cultures. Int. Dairy J. 17:826-834.

Sihufe, G. A., S. E. Zorrilla, D. J. Mercanti, M. C. Perotti, C. A. Zalazar, and A. Rubiolo. 2007. The influence of ripening temperature 
and sampling site on the lipolysis in Reggianito Argentino cheese. Food Res. Int. 40:1220-1226.

Somers, J., and A. Kelly. 2002. Contribution of plasmin to primary proteolysis during ripening of cheese: effect of milk heat treatment and cheese cooking temperature. Lait 82:181-191.

Sousa, M. J., Y. Ardö, and P. H. L. McSweeney. 2001. Advances in the study of proteolysis during cheese ripening. Int. Dairy J. 11:327345 .

Upadhyay, V., M. J. Sousa, P. Ravn, H. Israelsen, A. Kelly, and P. L. H. McSweeney. 2004. Use of exogenous streptokinase to accelerate proteolysis in Cheddar cheese during ripening. Lait 84:527-538.

Vélez, M. A., C. V. Bergamini, M. B. Ramonda, M. C. Candioti, E. R. Hynes, and M. C. Perotti. 2015b. Influence of cheese making tech- nologies on plasmin and coagulant associated proteolysis. Food Sci. Technol. 64:282-288.

Vélez, M. A., M. C. Perotti, S. R. Rebechi, and E. R. Hynes. 2015a. A new minicurd model system for hard cooked cheeses. J. Dairy Sci. 98:3679-3683.

Voigt, D. D., M. F. Patterson, M. Linton, and A. L. Kelly. 2011. Effect of high-pressure treatment of milk prior to manufacture on ripening of Camembert cheese. Innov. Food Sci. Emerg. Technol. 12:1-5.

Watkinson, P., C. Coker, R. Crawford, C. Dodds, K. Johnston, A McKenna, and N. White. 2001. Effect of cheese $\mathrm{pH}$ and ripening time on model cheese textural properties and proteolysis. Int. Dairy J. 11:455-464. 